\title{
Glutatyon, hepatit B virus enfeksiyonundan etkilenir mi?
}

\section{Is glutathione affected by hepatitis B virus infection?}

\author{
Halil Haldun Emiroğlu
}

${ }^{1}$ Selçuk Üniversitesi Tıp Fakültesi, Çocuk Sağlığı ve Hastalıkları AD, Çocuk Gastroenterolojisi BD, Konya

$\ddot{\mathbf{O z}}$

Glutatyon redoks sistemi yaştan etkilenebilir. Bu nedenle serum glutatyon düzeyleri ile ilgili çalışma yapıllıken, vaka ve kontrol gruplarına ait yaş ortalamalarının benzer olmasına özen gösterilmelidir.

\section{Abstract}

The glutathione redox system can be affected by age. For this reason, when conducting studies on serum glutathione levels, care should be taken to ensure that the mean ages of the case and control groups are similar.

Sayın Editör,

Genel Tip Dergisi'nin son sayısında [Genel Tıp Derg 2021;31(3)239-242] yayımlanan Şenol A tarafindan yazılan "Hepatit B Virus Enfeksiyonu ve Glutatyon" başıklı makaleyi ilgi ile okudum. Avrupa Karaciğer Araştırmaları Derneği (EASL) tarafından 2017 yılında yayımlanan rehbere (1) göre kronik hepatit B virüs (HBV) enfeksiyonu HBeAg pozitif kronik enfeksiyon, HBeAg pozitif kronik hepatit, $\mathrm{HBeAg}$ negatif kronik enfeksiyon ve $\mathrm{HBeAg}$ negatif kronik hepatit evrelerinden oluşmaktadır. Çalışmada kullanılan veriler yalnızca HBeAg negatif kronik enfeksiyon evresi ile ilgilidir.

Makalenin tablo 1 bölümü incelendiğinde hepatit B virüs enfeksiyonu olan grubun yaş ortalamasının (43.75 \pm 4.33 ) kontrol grubundan (29.31 \pm 1.59 ) daha yüksek olduğu görülmektedir $(\mathrm{p}=.004)$. Makalede HBV enfeksiyonunda, glutatyonun serum düzeylerinin kontrol grubundan düşük bulunduğu ( $\mathrm{p}=.001)$ bildirilmiş̧ir. Ancak, glutatyon redoks sisteminin yaştan etkilenebildiği daha önce yapılmıș olan çalıșmalarda gösterilmiștir (2-4). Erden-Inal ve arkadaşlarının 176 sağlıklı birevin verilerini içeren çalısmasında (3) 0.2-1 yas ve 41-69 yaş grubunda diğer yaş gruplarına göre glutatyon düzeylerinin daha düşük $(\mathrm{p}<.001)$ olduğu da bulunmuş̧ur. Bu nedenle "Hepatit B Virus Enfeksiyonu ve Glutatyon" başlıklı makalenin sonucu olarak HBV enfeksiyonlu kişilerde glutatyonun serum düzeylerinin düşük olduğu yorumunun yapılması uygun değildir. Çalışma, vaka ve kontrol gruplarına ait yaş ortalamalarının benzer olması sağlanarak yeniden yapılması durumunda sonuçlar daha doğru yorumlanabilir.

Kaynaklar

1.European Association for the Study of the Liver. EASL 2017 Clinical Practice Guidelines on the management of hepatitis B virus infection. J Hepatol. 2017; 67: 370-98.

2.Samiec PS, Drews-Botsch C, Flagg EW, et al. Glutathione in human plasma: decline in association with aging, age-related macular degeneration, and diabetes. Free Radic Biol Med. 1998; 24: 699-704.

3.Erden-Inal M, Sunal E, Kanbak G. Age-related changes in the glutathione redox system. Cell Biochem Funct. 2002; 20: 61-6.

4.Giustarini D, Dalle-Donne I, Lorenzini S, Milzani A, Rossi R. Age-related influence on thiol, disulfide, and protein-mixed disulfide levels in human plasma. J Gerontol A Biol Sci Med Sci. 2006; 61: 1030-8

Makalemin ilgiyle okunması ve yorum yazılması beni mutlu etti. EASL 2017 rehberine göre kronik hepatit B ile ilgili tanımlar değiști. Çalıșmada kullanılan veriler de editöre mektup yazısında belirtildiği gibi HBeAg negatif kronik enfeksiyon(eski adı inaktif taşıyıcı) evresi ile ilgilidir. Karaciğer inflamasyonu ve progresyonunda oksidan ve antioksidan sistemin etkilerinin değerlendirildiği çalışmalar giderek artmaktadır. Glutatyon da, karaciğerde bulunan en önemli antioksidanlardan biridir. Karaciğer hasarı, yaşlanma, kanser, kalp damar hastalıkları ve başka birç̧ok kronik/dejeneratif hastalıkların önlenmesinde de etkili olduğu bildirilmiştir. 20 yaşından sonra doğal glutatyon üretimi her on yılda ortalama \%10 azalmaktadır. Makalede, 18 yaş altı çalışma dışı bırakılmıştır. Vaka ve kontrol gruplarına ait yaş ortalamalarının benzer olması, yaşın etkisinden bağımsız olarak glutatyon düzeyinin değerlendirilmesi için faydalı olabilir. Ancak, antioksidan sistem, glutatyonun viral yükü ve sitokin kaynaklı hasarı azaltabilme ve antioksidan etkisi düşünüldüğünde bu yöndeki çalışmalar, gelecekteki çalışmalara ışık tutabilir.

Arzu ȘENOL

${ }^{1}$ Fethi Sekin Șehir Hastanesi, Enfeksiyon Hastalıkları ve Klinik Mikrobiyoloji, Elazı̆̆.

Yazışma Adresi: Halil Haldun Emiroğlu, Selçuk Üniversitesi Tıp Fakültesi, Çocuk Sağlığı ve Hastalıkları AD, Çocuk Gastroenterolojisi BD, Konya

E-Posta: haldunemiroglu@gmail.com

Alınma tarihi: 06.10.2021 / Kabul tarihi: 31.12.2021 / Yayımlanma tarihi: 15.12.2021

Glutatyon, hepatit B virus enfeksiyonundan etkilenir mi? - Emiroğlu.

Genel Tip Derg 2021;31(4)450 